\title{
Sistem Pendukung Keputusan Penerimaan Beasiswa Sekolah Menegah Atas Bireun Menggunakan Metode Fuzzy Topsis Study Kasus: Sma Negeri 1 Matangkuli
}

\author{
Iskandar Zulkarnaini \\ Teknik Informatika Universitas AlMuslim Bireuen \\ Jn. Almuslim, Matangglumpangdua-Bireuen, 2461 Aceh
}

\begin{abstract}
Abstrak - Sistem pendukung keputusan merupakan suatu sistem yang interaktif, yang membantu mengambil keputusan melalui penggunaan data dan model-model keputusan untuk memecahkan masalah yang sifatnya semi terstruktur maupun yang tidak terstruktur. Dalam penelitian ini sistem pendukung keputusan digunakan untuk menentukan siswa yang akan mendapatkan beasiswa menggunakan Metode TOPSIS. Proses seleksi penerima beasiswa merupakan proses pengambilan keputusan berdasarkan beberapa kriteria. Konsep dasar metode TOPSIS adalah mencari penjumlahan terbobot dari rating kinerja pada setiap alternatif calon penerima beasiswa pada semua kriterianya. Metode TOPSIS membutuhkan proses normalisasi matriks keputusan ke suatu skala yang dapat diperbandingkan dengan semua rating alternatif yang ada. Hasil akhirnya berupa suatu aplikasi Sistem Pendukung Keputusan dalam penyeleksian calon penerima beasiswa di SMA Negeri Bireun.
\end{abstract}

Keywords-SPK, TOPSIS, Fuzzy, Beasiswa

\section{PENDAHULUAN}

\subsection{Latar Belakang}

Undang -Undang Dasar 1945 pasal 31 (1) mengatur bahwa tiap-tiap warga Negara berhak mendapatkan pengajaran. Berdasarkan pasal tersebut, maka pemerintah pusat dan pemerintah daerah wajib memberikan layanan dan kemudahan, serta menjamin terselenggaranya pendidikan yang bermutu bagi setiap warga Negara tanpa diskriminasi. Untuk menyelenggarakan pendidikan yang bermutu diperlukan biaya pendidikan yang cukup besar. Oleh karena itu bagi setiap peserta didik pada setiap satuan pendidikan berhak mendapatkan biaya pendidikan bagi mereka yang orang tuanya tidak mampu membiayai pendidikannya, dan berhak mendapatkan beasiswa bagi mereka yang berprestasi.

Seleksi calon penerima beasiswa pada umumnya memiliki banyak kriteria seperti nilai akademik dalam hal ini adalah nilai raport, pendapatan dan tanggungan keluarga, jarak rumah, serta transportasi, dan lain sebagainya. Dengan banyaknya alternatif yang mempengaruhi sebuah keputusan maka sulit untuk mengambil sebuah keputusan secara manual serta kurang efektif jika kita mengacu pada kemajuan teknologi yang sudah sangat pesat pada saat sekarang ini.

Penerapan fuzzy dalam penelitian ini adalah untuk proses penilaian atau pembobotan dalam mengukur peringkat alternatif serta mengukur kepentingan masing-masing kriteria, selanjutnya akan dimasukkan kedalam proses metode topsis.

Oleh karena itu, perlu adanya suatu sistem yang mendukung proses penentuan penerima beasiswa, sehingga dapat mempersingkat waktu penyeleksian dan dapat meningkatkan kualitas keputusan dalam penentukan penerima beasiswa

\section{METODOLOGI PENELITIAN}

\subsection{Sistem Pendukung Keputusan}

Sistem pendukung keputusan adalah sekumpulan prosedur berbasis model untuk data pemrosesan dan penilaian guna membantu para manajer mengambil keputusan.

Konsep Sistem Pendukung Keputusan pertama kali diungkapkan pada awal tahun 1970-an oleh Michael S. Scott Morton dengan istilah Management Decision Systems yakni "Suatu sistem yang berbasis atau berbantuan komputer yanng ditujukan untuk membantu pengambilan keputusan dalam memanfaatkan data dan model tertentu untuk memecahkan berbagai persoalan yang tidak terstruktur" (Dadan Umar Daihani, 2001).

\subsection{FMADM}

Fuzzy Multiple Attribute Decision Making (FMADM) adalah suatu metode yang digunakan untuk mencari alternatif optimal dari sejumlah alternatif dengan kriteria tertentu. Inti dari FMADM adalah menentukan nilai bobot untuk setiap atribut, kemudian dilanjutkan dengan proses perankingan yang akan menyeleksi alternatif yang sudah diberikan. Pada dasarnya, ada 3 pendekatan untuk mencari nilai bobot atribut, yaitu pendekatan subyektif, pendekatan obyektif dan pendekatan integrasi antara subyektif \& obyektif. Masing-masing pendekatan memiliki kelebihan dan kelemahan. Pada pendekatan subyektif, nilai bobot ditentukan berdasarkan subyektifitas dari para pengambil 
keputusan, sehingga beberapa faktor dalam proses perankingan alternatif bisa ditentukan secara bebas. Sedangkan pada pendekatan obyektif, nilai bobot dihitung secara matematis sehingga mengabaikan subyektifitas dari pengambil keputusan (Sri Kusuma Dewi : 2006 ).

Ada beberapa metode yang dapat digunakan untuk menyelesaikan masalah FMADM. antara lain :

1. Simple Additive Weighting Method (SAW)

2. Weighted Product (WP)

3. ELECTRE

4. Technique for Order Preference by Similarity to Ideal Solution (TOPSIS)

5. Analytic Hierarchy Process (AHP)

\subsection{Metode TOPSIS}

TOPSIS (Technique For Others Reference by Similarity to Ideal Solution) adalah salah satu metode pengambilan keputusan multikriteria yang pertama kali diperkenalkan oleh Yoon dan Hwang pada tahun 1981. TOPSIS menggunakan prinsip bahwa alternatif yang terpilih harus mempunyai jarak terdekat dari solusi ideal positif dan terjauh dari solusi ideal negatif dari sudut pandang geometris dengan menggunakan jarak Euclidean untuk menentukan kedekatan relatif dari suatu alternatif dengan solusi optimal. Solusi ideal positif didefinisikan sebagai jumlah dari seluruh nilai terbaik yang dapat dicapai untuk setiap atribut, sedangkan solusi negatif-ideal terdiri dari seluruh nilai terburuk yang dicapai untuk setiap atribut.

TOPSIS mempertimbangkan keduanya, jarak terhadap solusi ideal positif dan jarak terhadap solusi ideal negatif dengan mengambil kedekatan relatif terhadap solusi ideal positif. Berdasarkan perbandingan terhadap jarak relatifnya, susunan prioritas alternatif bisa dicapai. Metode ini banyak digunakan untuk menyelesaikan pengambilan keputusan secara praktis. Hal ini disebabkan konsepnya sederhana dan mudah dipahami, komputasinya efisien,dan memiliki kemampuan mengukur kinerja relatif dari alternatifalternatif keputusan. Fatmi dkk (2013).

Berikut ini adalah langkah kerja dari metode TOPSIS :

1. TOPSIS dimulai dengan membangun sebuah matriks keputusan Matriks keputusan $\mathrm{X}$ mengacu terhadap $\mathrm{m}$ alternatif yang akan dievaluasi berdasarkan $\mathrm{n}$ kriteria.

$$
X=\begin{gathered}
a_{1} \\
a_{2} \\
a_{3} \\
\cdot \\
\cdot \\
a_{m}
\end{gathered}\left[\begin{array}{ccccccc}
x_{11} & x_{12} & x_{13} & \cdot & \cdot & \cdot & x_{1 n} \\
x_{21} & x_{22} & x_{23} & \cdot & \cdot & \cdot & x_{2 n} \\
x_{31} & x_{32} & x_{33} & \cdot & \cdot & \cdot & x_{3 n} \\
\cdot & \cdot & \cdot & \cdot & \cdot & \cdot & \cdot \\
\cdot & \cdot & \cdot & \cdot & \cdot & \cdot & \cdot \\
x_{m 1} & x_{m 1} & x_{m 1} & \cdot & \cdot & \cdot & x_{m n}
\end{array}\right]
$$

2. Membangun matriks keputusan ternormalisasi

Persamaan yang digunakan untuk mentransformasikan setiap elemen $x_{i j}$ adalah

Keterangan

$$
r_{i j}=\frac{x_{i j}}{\sqrt{\sum_{i=1}^{m} x_{i j}^{2}}}
$$

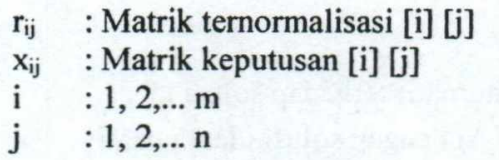

3. Membangun matriks keputusan ternormalisasi terbobot.

$$
y_{i j}=w r_{i j}
$$

Keterangan:

$\mathrm{y}_{\mathrm{ij}}$ : Matrik keputusan ternormalisasi terbobot

w : Bobot preferensi

$\mathrm{x}_{\mathrm{ij}}$ : Matrik keputusan

4. Menentukan solusi ideal positif dan solusi ideal negatif.

Solusi ideal dinotasikan $\mathrm{A}^{+}$, sedangkan solusi ideal negatif dinotasikan $\mathrm{A}^{-}$:

$$
\begin{gathered}
A^{+}=\left(Y_{1}^{+}, Y_{2}^{+}, Y_{3}^{+}, \ldots, Y_{n}^{+}\right) \\
A^{-}=\left(Y_{1}^{-}, Y_{2}^{-}, Y_{3}^{-}, \ldots, Y_{n}^{-}\right)
\end{gathered}
$$

Dengan ketentuan

$$
\begin{aligned}
& y_{j}^{+}=\left\{\begin{array}{l}
\max _{i} y_{i j} \\
\min _{i} y_{i j}
\end{array}\right. \\
& y_{j}^{-}=\left\{\begin{array}{l}
\min _{i} y_{i j} \\
\max _{i} y_{i j}
\end{array}\right.
\end{aligned}
$$

Keterangan :

$y_{j}^{+}$: Solusi ideal positif

$y_{j}^{-}$: Solusi ideal positif

$y_{i j}:$ Matrik keputusan ternormalisasi terbobot

w : Bobot preferensi

$r_{i j} \quad$ : Matrik Ternormalisasi

$A^{-}$: Solusi minimal ideal positif

$\mathrm{A}^{+} \quad$ : Solusi minimal ideal positif

i $: 1,2, \ldots \mathrm{m}$

Menghitung Solosi jarak Solusi Ideal Positif

$$
D_{i}^{+}=\sqrt{\sum_{j-1}^{n}\left(y_{i}^{+}-y_{i j}\right)^{2}}
$$

Keterangan :

$$
\begin{aligned}
& D_{i}^{+}: \text {Jarak Alternatif Ai dengan solusi ideal positif } \\
& y_{j}^{+}: \text {Solusi ideal positif } \\
& y_{\mathrm{ij}}: \text { Matrik keputusan ternormalisasi terbobot }
\end{aligned}
$$

Dan jarak terhadap solusi negatif-ideal didefinisikan sebagai:

$$
D_{i}^{-}=\sqrt{\sum_{j=1}^{n}\left(y_{i j}-y_{i}^{-}\right)^{2}}
$$

\section{Keterangan}

$D_{i}^{-}$: Jarak Alternatif Ai de (2.4) isi ideal negatif

$y_{j}^{-}$: Solusi ideal negatif

$\mathrm{y}_{\mathrm{ij}}$ : Matrik keputusan ternormalisasi terbobot 
5. Menghitung kedekatan relatif terhadap solusi ideal

$$
V_{i}=\frac{D_{i}^{-}}{D_{i}^{-}+D_{i}^{+}}
$$

Keterangan

$\mathrm{V}_{\mathrm{i}}$ : Kedekatan tiap alternatif terhadap solusi ideal

$D_{i}^{-}$: Jarak Alternatif $\mathrm{Ai}$ dengan solusi ideal negatif

$D_{i}^{+}$: Jarak Alternatif Ai dengan solusi ideal positif

\section{Merangking Alternatif}

Alternatif dapat dirangking berdasarkan urutan $\mathrm{Ci}_{i}^{+}$. Maka dari itu, alternatif terbaik adalah salah satu yang berjarak terpendek terhadap solusi ideal dan berjarak terjauh dengan solusi negatif-ideal.

\section{HASIL DAN PEMBAHASAN}

\subsection{Analisa Sistem}

Penilaian dilakukan dengan melihat nilai-nilai terhadap indikator yaitu Nilai Rapor, Penghasilan orangtua, Jumlah anak, Transportasi yang digunakan, Jarak rumah kesekolah. Selanjutnya masing-masing indikator tersebut dianggap sebagai kriteria yang akan dijadikan sebagai faktor untuk menentukan penerima beasiswa dan himpunan fuzzy nya adalah Sangat Rendah(SR), Rendah (R), Cukup (C), Tinggi (T), Sangat Tinggi (ST). Himpunan ini kemudian diperlakukan sebagai input kedalam sistem FMADM (dalam hal ini disebut sebagi $\mathrm{C}_{\mathrm{i}}$ ).

Variabel yang digunakan dalam penelitian ini adalah Rapor, Penghasilan orangtua, Jumlah anak, Transportasi yang digunakan, Jarak rumah kesekolah dan untuk himpunan fuzzynya adalah Sangat Rendah(SR), Rendah (R), Cukup (C), Tinggi (T), Sangat Tinggi (ST).

Input untuk melakukan proses pengambilan keputusan dari beberapa alternatif ini dilakukan dengan menggunakan kuesioner.

Keluaran yang dihasilkan dari penelitian ini adalah sebuah alternatif yang memiliki nilai tertinggi dibandingkan dengan alternatif nilai yang lain. Pada penelitian ini hasil keluarannya diambil dari urutan alternatif tertinggi ke alternatif terendah. Hasil akhir yang dikeluarkan oleh program nanti berasal dari nilai setiap kriteria, karena dalam setiap kriteria memiliki nilai yang berbeda-beda.

Urutan alternatif yang akan ditampilkan mulai dari alternatif tertinggi ke alternatif terendah. Alternatif yang dimaksud adalah siswanya.

\subsection{Kriteria Yang Dibutuhkan}

\subsubsection{Nilai Rapor}

Variabel Nilai Rapor dikonversikan dengan bilangan fuzzy dibawah ini.

\begin{tabular}{|l|l|l|}
\hline $\begin{array}{c}\text { NILAI } \\
\text { RAPOR }\end{array}$ & KETERANGAN & NILAI \\
\hline$<=60$ & Sangat Rendah & .05 \\
\hline $61-70$ & Rendah & .25 \\
\hline $71-80$ & Cukup & .50 \\
\hline $81-90$ & Tinggi & .75 \\
\hline $91-100$ & Sangat Tinggi & \\
\hline
\end{tabular}

\subsubsection{Penghasilan orangtua}

Variabel Penghasilan Orangtua dikonversikan dengan bilangan fuzzy dibawah ini.

\begin{tabular}{|l|l|l|}
\hline PENGHASILAN & KETERANGAN & NILAI \\
\hline$<=1 \mathrm{jt}$ & Sangat Rendah & \\
\hline $1 \mathrm{jt}-2 \mathrm{jt}$ & Rendah & .75 \\
\hline $3 \mathrm{jt}-4 \mathrm{jt}$ & Cukup & .50 \\
\hline $5 \mathrm{jt}-6 \mathrm{jt}$ & Tinggi & .25 \\
\hline$>=7 \mathrm{jt}$ & Sangat Tinggi & .05 \\
\hline
\end{tabular}

\subsubsection{Jumlah anak}

Variabel Jumlah Anak dikonversikan dengan bilangan fuzzy dibawah ini.

\begin{tabular}{|l|l|l|}
\hline JUMLAH & KETERANGAN & NILAI \\
\hline 1 Anak & Sangat Rendah & .05 \\
\hline 2-3 Anak & Rendah & .25 \\
\hline 4-5 Anak & Cukup & .50 \\
\hline 6-7 Anak & Tinggi & .75 \\
\hline $\begin{array}{c}\text { 8 Anak/ } \\
\text { Lebih }\end{array}$ & Sangat Tinggi & \\
\hline
\end{tabular}

\subsubsection{Transportasi}

Variabel Transportasi di konversikan dengan bilangan fuzzy dibawah ini.

\begin{tabular}{|l|l|l|}
\hline TRANSPORTASI & KETERANGAN & NILAI \\
\hline Jalan Kaki & Rendah & 1 \\
\hline Sepeda & Cukup & 0.75 \\
\hline Sepeda Motor & Tinggi & 0.50 \\
\hline Mobil & Sangat Tinggi & 0.25 \\
\hline
\end{tabular}

\subsubsection{Jarak rumah}

Variabel jarak rumah di konversikan dengan bilangan fuzzy dibawah ini.

\begin{tabular}{|c|l|l|}
\hline JARAK RUMAH & KETERANGAN & NILAI \\
\hline$<=1 \mathrm{KM}$ & Sangat Rendah & 0.05 \\
\hline $2 \mathrm{KM}-3 \mathrm{KM}$ & Rendah & 0.25 \\
\hline $4 \mathrm{KM}-5 \mathrm{KM}$ & Cukup & 0.50 \\
\hline $6 \mathrm{KM}-7 \mathrm{KM}$ & Tinggi & 0.75 \\
\hline$>=8 \mathrm{KM}$ & Sangat Tinggi & 1 \\
\hline
\end{tabular}

3.4.6 Implementasi SismForm Data Siswa

Adapun form data siswa untuk inputan adalah sebagai berikut:

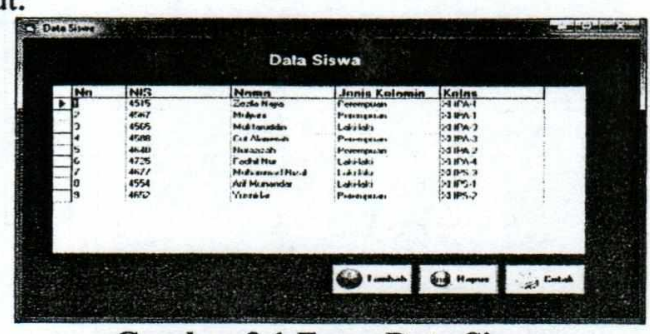

Gambar 3.1 Form Data Siswa

Form Perhitungan TOPSIS

Adapun form untuk perhitungan topsis adalah sebagai berikut: 


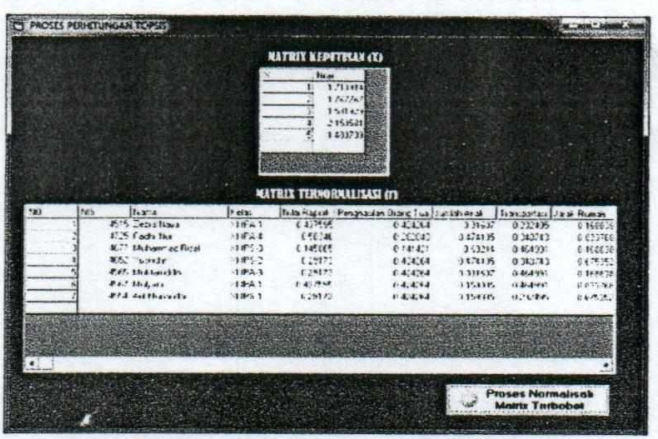

Gambar 3.2 Form Data Siswa

\section{REFERENSI}

[1] Dadan Umar Daihani, 2001, Komputerisasi Pengambilan Keputusan, Penerbit Elex Media Komputindo, Jakarta.

[2] Kusumadewi, Sri., Hartati, Sri., Harjoko, Agus., Wardoyo, Retantyo., 2006, Fuzzy Multi-Attribute Decision Making (FUZZY MADM), Penerbit Graha ilmu, yogyakarta.

[3] Fatmi M, Dkk Sistem Pendukung Keputusan penerimaan karyawan memgunakan Metode Topsis, 2013.

Form Normalisasi terbobot, Solusi ideal pisitif dan solusi ideal negatif

Adapun untuk masing-masing nilai proses topsis adalah sebagai berikut:

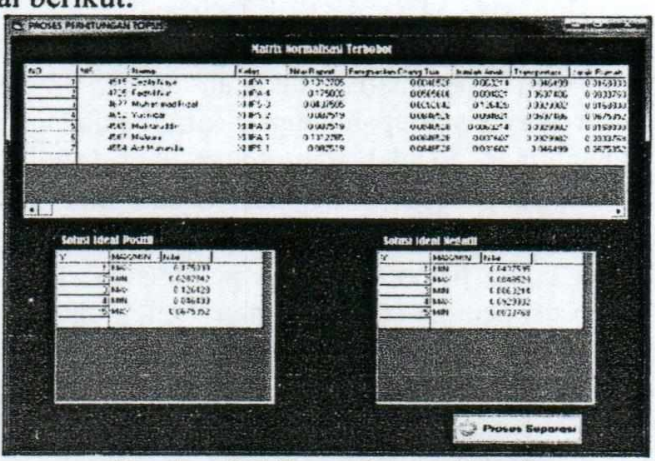

Gambar 3.3 Form Proses Topsis

Form Hasil Perangkingan

Adapun untuk masing-masing perangkingan penerimaan beasiswa adalah sebagai berikut:

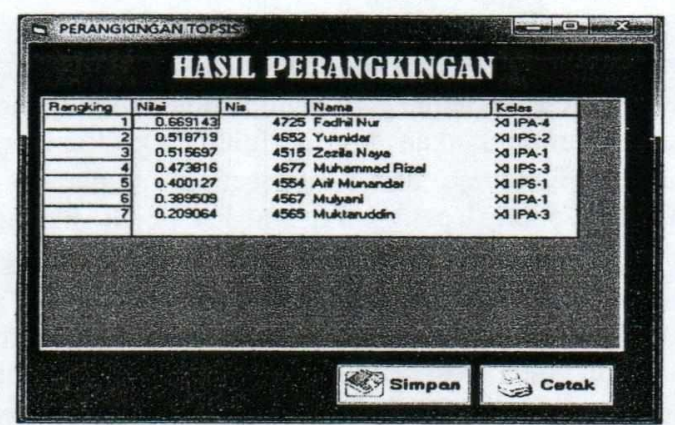

Gambar 3.4 Hasil Perangkingan

\section{KESIMPULAN}

Dari penelitian diatas penulis mengambil kesimpulan, sebagai berikut:

1. Aplikasi Sistem Pendukung Keputusan menggunakan metode TOPSIS ini di gunakan untuk Memilih siswa Penerima Beasiswa sesuai dengan kriteria yang telah di tentukan.

2. Dapat membantu Kepala Sekolah dalam merekomendasi siswa yang dapat diberikan beasiswa 